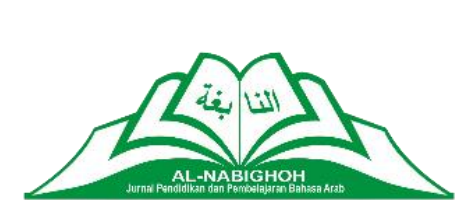

\title{
PERSEPSI MAHASISWA TERHADAP PENGGUNAAN KAMUS DIGITAL BAHASA ARAB DI ERA SOCIETY 5.0
}

\author{
Ahmad Arifin ${ }^{*}$, Slamet Mulyani2 \\ ${ }^{1}$ Institut Agama Islam Negeri Metro, Indonesia \\ ${ }^{2}$ Sekolah Tinggi Agama Islam Negeri Bengkalis, Indonesia
}

\section{Article Info}

\section{Article History:}

Received: October 2021

Revised: December 2021

Accepted: December 2021

Published: December 2021

*Corresponding Author:

Name: Ahmad Arifin

Email:

arifin@metrouniv.ac.id

\section{Abstract}

The Arabic dictionary is the primary reference for students learning Arabic, mainly when translating. With advances in technology, dictionaries are no longer in sheets of paper but in digital form that mobile phones and desktops can be accessed. This study aimed to determine students' perceptions of the use of digital dictionaries and various aspects of the difficulties experienced by students. This exploratory research was conducted using a survey technique on randomly selected students, and a descriptive technique was used as an analytical tool. The number of respondents is as many as 100 students from 2 different universities. In general, answers related to students' perceptions can be mapped in several ways: 1) students' ability to translate is still low. 2) students still have many difficulties when translating and how to use a dictionary. 3) dictionaries are still required, both digital and print. 4) google translate became the student's favorite dictionary. So, the author recommends special training in dictionaries at the beginning of lectures at the higher education level.

Copyright (C) 2021, Ahmad Arifin, Slamet Mulyani This is an open-access article under the CC-BY-SA license

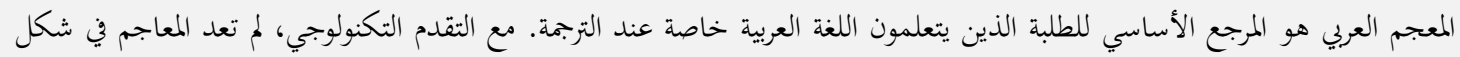
أوراق ورقية ولكن في شكل رقمي يمكن الوصول إليه من الهواتف المحمولة وأجهزة الكمبيوتر المكتبية. هدفت هذه الدراسة إلى تحديد المهيد

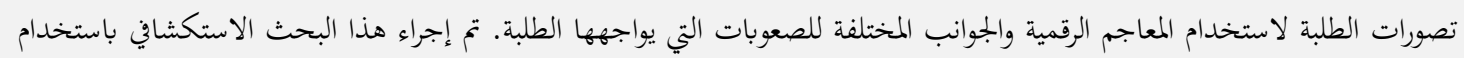

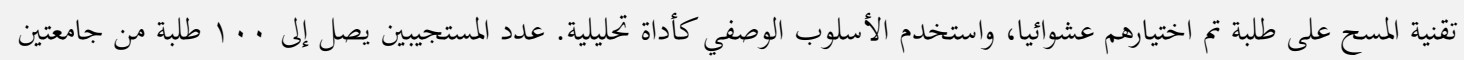

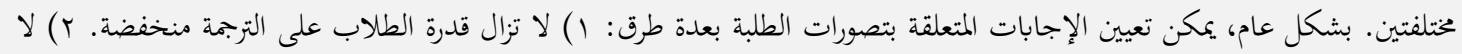

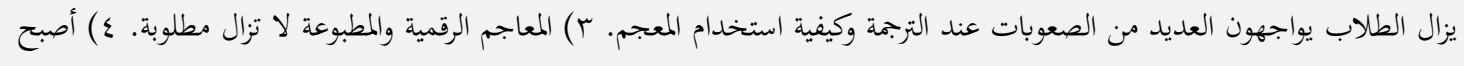
ترجمة جوجل، المعجم المفضل لدى الطلبة. لذلك يوصي الباحث بتدريب خاص في المعاجم على مستوى التعليم العالي في بداية المحاضرات.

$$
\text { كلمات أساسية: المعجم الرقمي؛ تعلم اللغة العببة؛ العصر .0. }
$$




\section{Pendahuluan}

Zaman serba digital di era Society 5.0, mahasiswa masa kini tentu sangat terbantu dengan adanya berbagai kemajuan khususnya untuk menunjang pembelajaran mereka. Begitu pun dalam urusan pencarian sumber belajar, yang tentunya begitu melimpah di dunia maya. Tentu, perlu pengetahuan mendasar untuk memilah mana sumber belajar yang kredibel dan dapat dipergunakan. Dalam mempelajari bahasa Arab, seorang mahasiswa terkadang kesulitan dalam memahami arti dari kosakata yang ada dalam suatu kalimat. Tentu dibutuhkan kamus untuk mengetahui dan memahami arti secara baik dan benar. Oleh karenanya kamus Arab merupakan salah satu referensi utama mahasiswa dalam mempelajari bahasa Arab. Dengan kemajuan teknologi, kamus bukan lagi berbentuk lembaran-lembaran kertas, namun sudah berbentuk digital yang dapat diakses dengan berbagai media yang ada diantaranya: smartphone, tablet, desktop, laptop, dan lainnya.

Era Society 5.0 pertama kalinya dikembangkan oleh Jepang, yang kemudian dianggap sebagai sebuah konsep society (masyarakat) yang terpusat pada manusia serta berbasiskan pada teknologi. Konsep tersebut hadir sebagai upaya pengembangan dari Fourth Industrial Revolution atau sering dikenal sebagai Revolusi Industri 4.0. Dengan terwujudnya Society 5.0 seseorang, suatu benda, dan lainnya semua dapat terkoneksi dalam dunia maya, optimalisasi hasil yang didapatkan oleh Artificial Intelligence (kecerdasan buatan) beserta kolaborasi dengan teknologi Big Data yang dapat melebihi kemampuan manusia pada umumnya dan disediakan timbal balik pada sebuah ruang fisik. ${ }^{1}$ Sesuai dengan literatur pemerintah Jepang, Society 5.0 harus menjadi salah satu penggabungan tingkat tinggi antara dunia maya dan ruang fisik, yang akan dapat memberikan keseimbangan dalam bidang ekonomi dan permasalahan sosial. Kebutuhan tanpa memandang tempat, usia, jenis kelamin, ataupun bahasa. Sedangkan visi Society 5.0 mengharuskan manusia untuk membingkai ulang hubungan antara teknologi dan masyarakat serta hubungan yang disaranai teknologi antara suatu individu dan masyarakat. ${ }^{2}$

Bahasa terus menerus mengalami perubahan seiring dengan berkembangnya masyarakat. Adanya kamus tentu tidak bisa menerjemahkan semua istilah atau kosakata baru yang terlahir dari proses perkembangan bahasa di masyarakat tersebut. Di samping itu kamus yang sudah disusun harus secara periodik memperbaharui edisi seiring dengan penambahan istilah atau kosakata baru yang muncul. Jadi dapat dikatakan bahwa tidak ada kamus yang lengkap, namun lebih

1 Kristien Margi Suryaningrum, "Siapkah Indonesia Menyosong Society 5.0 dengan Seiring Perkembangan Big Data yang Semakin Pesat?," School of Computer Science - Binus University, diakses 19 Desember 2021, https://socs.binus.ac.id/2020/11/01/siapkah-indonesia-menyosong-society-5-0dengan-seiring-perkembangan-big-data-yang-semakin-pesat/.

2 Atsushi Deguchi dkk., "What Is Society 5.0?," dalam Society 5.0: A People-Centric Super-Smart Society (Singapore: Springer, 2020), 1-23, https://doi.org/10.1007/978-981-15-2989-4_1. 
sesuai jika disebut kamus yang baik, yang memenuhi standar baku yang disepakati. $^{3}$

Kamus secara bahasa bisa diartikan sebagai referensi yang dipakai oleh siswa dan pengajar ketika mengalami kesulitan dalam memahami suatu kata saat ditemui dalam bacaan ataupun ketika mendengarkan pernyataan orang lain. Hal lain juga terjadi ketika kesulitan memahami kosakata, kata-kata dan istilah. Terlebih bahasa yang ditemui yakni bahasa yang digunakan oleh orang-orang terdahulu pada zaman sebelumnya. ${ }^{4}$ Dengan begitu kamus bisa dipahami sebagai suatu bentuk karya acuan atau rujukan yang terdiri dari kata dan ungkapan, ditentukan berdasarkan abjad atau suatu tema, dan mengandung keterangan tentang arti, penggunaan, ataupun terjemahan. Sehingga kamus merupakan salah satu media bantu dalam mengetahui bahasa asing.

Kamus berbahasa arab secara lengkap disusun pertama kali oleh Al-Khalil ibn Ahmad yang hidup pada abad ke 2 hijriah (100-115 H/718-786 M) yang dinamai dengan Mu'jam Al-'Ain, kemudian diikuti oleh kamus-kamus lainnya hingga pada masa ini. ${ }^{5}$ Adapun karakteristik Mu'jam Al-'Ain sebagai berikut: 1) Kamus pertama dalam sejarah leksikologi Arab. 2) Kamus yang disusun menurut jumlah huruf, dan tiap hurufnya diklasifikasikan dalam satu kitab 3) Pencarian katanya dengan melihat asal usul kata 4) Diperingkas oleh Zubaidi dalam karya kamus yang berjudul Mukhtshar Al-'Ain. ${ }^{6} \mathrm{Al}$ Khalil terkenal karena membayangkan deskripsi asli dan formal bahasa Arab dengan memperhitungkan struktur kerangka yang mendasari bahasa Arab, berdasarkan fitur fonetiknya, yang diwujudkan dalam derivasi. Kamus Arab sejak masa penulisannya kali pertama hingga abad ke-20 M terdapat tiga konsep dalam ilmu shorof yang digunakan untuk membedah kamus, yakni konsep tentang tajrid, i'lal, dan bina'. ${ }^{7}$

Dalam penggunaan istilah linguistik modern, terdapat perbedaan antara leksikologi dengan leksikografi. Adapun leksikologi fokus pada pembahasan kosakata dan maknanya dalam satu bahasa ataupun beberapa bahasa. Sedangkan leksikografi cenderung ke dalam pembahasan tentang langkah-langkah dasar dalam memproduksi kamus. Jadi leksikografi bisa dikatakan bergantung pada leksikologi namun keduanya bukan satu hal yang sama. ${ }^{8}$ Leksikologi merupakan

${ }^{3}$ Khoirurrijal dkk., Interpretasi Makna (Prosedur Penerjemahan Arab - Indonesia) (Yogyakarta: Idea Press, 2019), 29.

4 Uril Bahruddin, Afaq Al-Ma'ajim Al-Arabiyyah (Malang: CV Lisan Arabi, 2020), 3, http://repository.uin-malang.ac.id/6004/.

${ }^{5}$ Muhammad Ahmad Abu Al-Faraj, Al-Ma'ajim Al-Lughawiyah fi Dhau'i Dirasat Ilmi Al-Lughah AlHadits (Beirut: Daar An-Nahdlah Al-Arabiyah, 1966), 25.

6 Prabowo Adi Widayat, "Kitābu Al-'Ain: Metode Penggunaan Dan Pengaruhnya Dalam Perkembangan Kosakata Bahasa Arab," Al-Fathin: Jurnal Bahasa Dan Sastra Arab 2, no. 01 (2019): 95, https://doi.org/10.32332/al-fathin.v2i2.1424.

7 Umi Nurun Ni'mah, "Perkembangan 'Ilm Al-Ṣarf Dalam Leksikologi Arab," Adabiyyāt: Jurnal Bahasa Dan Sastra 3, no. 1 (2019): 26-52, https://doi.org/10.14421/ajbs.2019.03102.

${ }^{8}$ Ali Al-Qasimy, Ilm Al-Lughah wa Shina'ah al-Mu'jam (Riyadh: Jami'ah Al-Mulk Su'ud, 1991), 3. 
kajian linguistik teoritis yang membahas kosakata dan maknanya. Sedangkan leksikografi merupakan salah satu bagian dari linguistik terapan yang diartikan sebagai pengetahuan dan seni penyusunan kamus bahasa dengan sistematika tertentu untuk menghasilkan produk kamus lengkap, memudahkan, dan berkualitas. Kedua ilmu tersebut tak bisa dipisahkan, karena tanpa leksikografi, leksikologi hanyalah kajian teoritis dan hanya memperdebatkan makna tanpa dapat memproduksi kamus yang berkualitas. ${ }^{9}$

Perkembangan kamus bahasa Arab di Indonesia berdasarkan sejarah disebutkan bahwa penyusunan kamus bahasa Arab dimulai dengan sistem morfologi. Sampai saat ini kamus dengan sistem morfologi masih digunakan. Keuntungannya adalah bahwa hal itu dinilai lebih lengkap; fungsi dan manfaat kamus terpenuhi; ini membantu siswa mempelajari dasar-dasar ilmu Sharaf (morfologi). ${ }^{10}$ Sedangkan jika dilihat berdasarkan pedoman penulisan kamus dwibahasa dinyatakan bahwa Kamus dwibahasa (dua bahasa/bilingual) mempergunakan dua bahasa, yakni bahasa sumber dan bahasa sasaran. Adapun pada bahasa sumber digunakan sebagai objek inventarisasi yang ditempati sebagai masukan kamus. Selanjutnya, masukan yang berasal dari bahasa sumber tersebut diberikan penjelasan arti ke dalam bahasa sasarannya. ${ }^{11}$

Penggunaan kamus elektronik telah lebih banyak menarik minat dibandingkan kamus cetak, hal tersebut karena efektivitas dan efisiensi dalam penggunaannya. Fakta tersebut didukung tuntutan kebutuhan siswa di era yang cepat berubah ini karena mereka dikategorikan sebagai digital native (generasi milenial, Generasi Z, dan Generasi Alpha) yang mampu mengoperasikan teknologi. Kamus elektronik lebih mudah diakses, beragam, lengkap, murah, dapat diperbarui dan diperbaiki. Selain itu dapat dikembangkan oleh siapa pun dan kapan pun, baik oleh suatu perusahaan maupun perorangan. Sistematika dalam penyusunan kamus elektronik khususnya bahasa Arab jauh lebih baik. Namun, fitur penerjemahan teks dalam kamus elektronik masih belum mampu menerjemahkan teks dengan benar sesuai kaidah gramatikal bahasa Arab. Lembaga pendidikan atau lembaga bahasa, perlu menghasilkan kamus elektronik bahasa Arab yang berkualitas dan kredibel agar dapat digunakan oleh dosen, mahasiswa, peneliti, dan masyarakat. Dengan demikian, mereka dapat menemukan aplikasi kamus elektronik terjemahan bahasa Arab yang sangat direkomendasikan. ${ }^{12}$

\footnotetext{
${ }^{9}$ Fitra Hayani, “Leksikografi Arab (Sebuah Kajian Linguistik Terapan)," Shaut al Arabiyyah 7, no. 1 (2019): 1-12, https://doi.org/10.24252/saa.v1i1.7786.

10 R. Taufiqurrochman, "Advantages and Disadvantages of Arabic Dictionary Applying Morphological System For Learning Arabic in Indonesia," LiNGUA: Jurnal IImu Bahasa Dan Sastra 14, no. 2 (2019): 271, https://doi.org/10.18860/ling.v14i2.8316.

11 Adi Sunaryo, Ahmad Patoni, dan Umi Basiroh, Pedoman Penyusunan Kamus Dwibahasa (Jakarta: Departemen Pendidikan dan Kebudayaan, 1990), 3, http://repositori.kemdikbud.go.id/3297/.

${ }^{12}$ R. Taufiqurrochman dan Dewi Suci, "Student's Perception of E-Dictionary Arabic Indonesian in IR 4.0 Era," dalam Proceedings of the 2nd International Conference on Quran and Hadith Studies Information Technology and Media in Conjunction with the 1st International Conference on Islam,
} 
Istilah kamus digital merupakan salah satu pilihan bagi pengguna untuk menyelesaikan problem yang ditemui saat tidak mengetahui kosakata baru. Terkait jenis kamus digital telah banyak tersedia, salah satunya yaitu kamus digital Arab - Indonesia yang terdapat di Google Play Store. Kamus Arab - Indonesia disarankan untuk dipakai dengan pertimbangan dapat menjadi salah satu sumber dalam pencarian kosakata dari bahasa Arab ke bahasa Indonesia ataupun sebaliknya. Selain itu, terkandung banyak kosakata dalam kamus tersebut serta dapat digunakan meskipun tidak terkoneksi dengan internet. ${ }^{13}$

Hasil temuan Belkhouche, dkk menyatakan bahwa yang terutama sebenarnya perlunya meningkatkan penggunaan kamus bahasa Arab di kalangan anak-anak untuk mendorong mereka belajar lebih banyak kosakata secara mandiri. Meskipun kamus bahasa Arab pertama dikembangkan sekitar 1500 tahun yang lalu, keadaan seni kamus bahasa Arab belum banyak mengalami kemajuan dan tertinggal jauh dari kamus bahasa lain. Kamus untuk anak-anak dapat didesain sebagaimana suatu permainan game dalam tingkat interaktivitasnya. Dengan demikian menyediakan suasana yang imajinatif bagi anak-anak untuk secara antusias mengeksplorasi lebih banyak konsep, gambar, dan kosakata. ${ }^{14}$

Dalam kamus Al-Munawwir, khusus untuk pencantuman kata-kata yang berantonim, hendaknya para pemakai mengecek ulang keantoniman kata tersebut. Karena masih dirasa agak rancu. Meskipun kamus al-Munawwir tak mengikut sertakan sumber entri, namun terlihat dari isinya sudah tergolong kamus standar yang dapat digunakan oleh siapa pun. Sekaligus ditambah dengan penggunaan bahasa yang relatif mudah dimengerti. Walaupun dalam beberapa segi masih terdapat kekurangan, namun masih dimaklumi sebab dengan kelebihan kamus tersebut sangat cukup untuk mengganti kekurangan yang ada di dalam kamus. ${ }^{15}$

Kamus Mahmud Yunus sebagai karya leksikografis, juga tak luput dari suatu kritik dari segi metodologi penyusunan maupun substansi dan penerjemahannya. Meskipun, kamus tersebut patut mendapatkan apresiasi sebagai suatu karya leksikografis rintisan yang bertujuan untuk memberikan fasilitas pengkaji bahasa Arab. Kamus tersebut juga dapat masuk dalam kategori kamus bilingual yang bersistematika shorfi dan disusun secara alfabetis. Kamus tersebut juga termasuk

Science and Technology (Bandung: European Alliance for Innovation, 2018), https://eudl.eu/doi/10.4108/eai.2-10-2018.2295473.

${ }^{13}$ Humairatuz Zahrah, Wildana Wargadinata, dan Nurhasan Abdul Barry, "Analisis E-Dictionarry 'Arab-Indonesia' yang Tersedia di Playstore dengan Pendekatan Leksikologi," Shaut al Arabiyyah 9, no. 1 (2021): 1-10, https://doi.org/10.24252/saa.v9i1.21494.

14 B. Belkhouche dkk., "What is a modern Arabic dictionary?" (2011 International Conference on Innovations in Information Technology, Abu Dhabi: Institute of Electrical and Electronics Engineers, 2011), 67-70, https://doi.org/10.1109/innovations.2011.5893870.

${ }^{15}$ Khasanah, Habib Bawafi, dan Asyief El Qorny, "Kamus Al-Munawwir Dalam Bingkai LeksikologiSemantik," Jurnal Al Fikrah 3, no. 2 (2021): 125, http://jurnal.stitalmuslihuun.ac.id/index.php/jurnal/article/view/99. 
perpaduan kamus umum dan kamus bergambar, sebab dilengkapi juga dengan berbagai gambar yang disadur dari kamus al-Munjid. ${ }^{16}$

Adapun kesalahan umum yang dilakukan oleh penerjemah pemula dalam menerjemahkan bahasa Arab ke dalam bahasa Indonesia di antaranya yakni sebagai berikut: 1) Kesalahan yang berhubungan dengan topik. 2) Kesalahan yang berhubungan dengan konotasi. 3) Kesalahan yang berhubungan dengan idiom. 4) Kesalahan yang berhubungan dengan makna figuratif. 5) Kesalahan yang berhubungan dengan diksi. 5) Kesalahan yang berhubungan dengan nama diri dan peristiwa sejarah. 6) Kesalahan yang berhubungan dengan singkatan dan akronim. 7) Kesalahan yang berhubungan dengan kecerobohan dan kekakuan. 8) Kesalahan yang berhubungan dengan kata tugas, konjungsi, dan partikel. ${ }^{17}$ Hal tersebut ditandai dengan banyaknya mahasiswa yang langsung percaya dengan hasil terjemahan mesin terjemahan misalnya: google translate.

Dalam artikel ini penulis mencoba menyingkap persepsi mahasiswa tentang kamus digital di era yang serba berkemajuan teknologi. Dengan mencoba memaparkan data-data hasil survei terkait: tingkat penguasaan mahasiswa dalam menerjemahkan, kesulitan saat menerjemahkan, kesulitan dalam proses penggunaan kamus, frekuensi dalam penggunaan kamus, jenis kamus yang digunakan untuk menerjemahkan, kebutuhan kamus digital, perbandingan keefektifan antara kamus digital dan kamus cetak, tingkat akurasi hasil terjemahan kamus digital, dan jenis kamus favorit.

\section{Metode Penelitian}

Penelitian ini merupakan penelitian eksploratif yang bersifat deskriptif dengan teknik survei. Survei dapat menjadi cara yang efektif untuk menggambarkan suatu fenomena. Survei deskriptif berulang yang diambil dari waktu ke waktu dapat menggambarkan suatu perubahan. ${ }^{18}$ Data diperoleh dengan instrumen kuesioner. Keseluruhan data dari hasil kuesioner dianalisa dengan menggunakan teknik statistik deskriptif untuk menyederhanakan, menganalisis, serta mendeskripsikan karakteristik utama data. ${ }^{19}$ Terdapat 100 responden yang mengisi kuesioner yang telah peneliti sebarkan melalui google form. Seluruh responden berasal dari dua perguruan tinggi yang berbeda, yaitu Institut Agama Islam Negeri Metro Lampung dan Sekolah Tinggi Agama Islam Negeri Bengkalis Riau.

\footnotetext{
${ }^{16}$ Muhbib Abdul Wahab, "Peta Perkembangan Leksikografi Arab Di Indonesia: Studi Kritis Atas Kamus Karya Mahmud Yunus," Arabi: Journal of Arabic Studies 2, no. 1 (2017): 19-36, https://doi.org/10.24865/ajas.v2i1.31.

17 Moch. Syarif Hidayatullah, Jembatan Kata: Seluk-Beluk Penerjemahan Arab-Indonesia (Jakarta: Grasindo, 2017), 28.

18 David de Vaus, Research Methods for Postgraduates, ed. oleh Tony Greenfield dan Sue Greener, Third edition (Chichester, UK ; Hoboken, NJ: John Wiley \& Sons, 2016), 203.

${ }^{19}$ Zealure C Holcomb, Fundamentals of Descriptive Statistics (London: Routledge, 2016).
} 


\section{Hasil dan Pembahasan}

Adapun rincian 100 responden terdiri dari mahasiswa berjenis kelamin lakilaki yakni 17 mahasiswa dan perempuan sebanyak 83 mahasiswa. Seluruh responden berasal dari dua perguruan tinggi yang berbeda, yaitu Institut Agama Islam Negeri Metro Lampung dan Sekolah Tinggi Agama Islam Negeri Bengkalis Riau, serta berasal dari 3 program studi yaitu: Prodi Bahasa Arab 42 orang, Prodi agama 30 orang, dan prodi umum 28 orang. Sedangkan terkait latar belakang pendidikan masing-masing mahasiswa pada jenjang pendidikan menengah yaitu Madrasah Aliyah \& Pesantren: 23 orang; Madrasah Aliyah \& Non-Pesantren: 32; SMA/SMK \& Pesantren: 8; SMA/SMK \& Non-Pesantren: 37 orang.

Dalam menerjemahkan teks berbahasa Arab bagi seorang penerjemah pasti akan menemui problem yang terkait dengan berbagai aspek yaitu aspek kebahasaan, non kebahasaan, dan kebudayaan. ${ }^{20}$ Berkaitan dengan hal tersebut, persepsi mahasiswa mengenai keterampilan menerjemahkan teks berbahasa Arab yang berdasarkan hasil survei menyatakan bahwa tingkat kesulitan menerjemah bagi mahasiswa secara umum masih berada pada level sulit. Artinya mahasiswa tanpa bekal pengetahuan dan dasar-dasar ilmu bahasa Arab pasti akan menganggap sulit jika diminta untuk menerjemahkan teks dengan baik dan benar. Hal tersebut tergambar dalam tabel 1.

Tabel 1. Persepsi mahasiswa tentang tingkat keterampilan menerjemahkan

\begin{tabular}{ccc}
\hline Jawaban & Frekuensi & Persentase \\
\hline Sangat sulit & 10 & $10 \%$ \\
Sulit & 58 & $58 \%$ \\
Mudah & 30 & $30 \%$ \\
Sangat Mudah & 2 & $2 \%$ \\
\hline
\end{tabular}

Berdasarkan hasil temuan Umi Hanifah permasalahan yang sering ditemui oleh penerjemah di antaranya berkaitan dengan hal-hal berikut: 1) Menerjemahkan itu sulit. 2) Perbedaan substansi bahasa bahasa Arab dan bahasa Indonesia. 3) Minimnya penguasaan bahasa sehingga terjadinya interferensi. 4) Kurangnya penguasaan teori-teori menerjemah. ${ }^{21}$ Hal tersebut senada dengan hasil survei kepada mahasiswa tentang kesulitan yang dialami saat menerjemahkan teks. Pada umumnya tidak menguasai gramatikal yaitu nahwu shorof, yang merupakan dasar dalam pembelajaran bahasa Arab. Lebih jelasnya dapat dilihat pada tabel 2.

${ }^{20}$ Siti Shalihah, “Menerjemahkan Bahasa Arab: Antara Ilmu Dan Seni,” At-Ta'dib 12, no. 1 (2017): 157, https://doi.org/10.21111/at-tadib.v12i1.867.

21 Umi Hanifah, "Urgensi Pembelajaran Menerjemah Arab-Indonesia Pada Perguruan Tinggi Agama Islam Di Indonesia," Alfazuna: Jurnal Pembelajaran Bahasa Arab dan Kebahasaaraban 2, no. 2 (2018): 204, https://doi.org/10.15642/alfazuna.v2i2.259. 
Tabel 2. Persepsi mahasiswa tentang kesulitan yang dialami saat menerjemahkan

\begin{tabular}{ccc}
\hline Jawaban & Frekuensi & Persentase \\
\hline Kosakata baru & 14 & $14 \%$ \\
Menyusun kalimat & 19 & $19 \%$ \\
Gramatikal (nahwu shorof) & 36 & $36 \%$ \\
Semuanya & 31 & $31 \%$ \\
\hline
\end{tabular}

Di samping hal di atas, masalah juga timbul dalam cara penggunaan kamus. Bagi pengguna dituntut untuk mengetahui cara menggunakan kamus dengan baik dan benar. Hal tersebut didukung oleh hasil penelitian yang dilakukan oleh Agung Setiyawan menyatakan bahwa jalan keluar yang bisa dilakukan untuk meminimalkan kesulitan dalam penggunaan kamus berbahasa Arab, ketika menerjemahkan teks bahasa Arab yaitu dengan menguasai nahwu shorof sebab secara umum kamus menampilkan kosakata dalam bentuk asalnya. Sedangkan untuk memudahkan dalam penentuan makna sebuah kata, hendaklah perbanyak latihan dalam menerjemahkan teks. ${ }^{22}$ Adapun persepsi mahasiswa terkait kesulitan dalam menggunakan kamus di antaranya tertuang dalam tabel 3.

Tabel 3. Kesulitan mahasiswa dalam penggunaan kamus

\begin{tabular}{ccc}
\hline Jawaban & Frekuensi & Persentase \\
\hline Mencari keberadaan suatu kata & 12 & $12 \%$ \\
Menentukan akar suatu kata & 24 & $24 \%$ \\
Menentukan makna kata & 34 & $34 \%$ \\
Semuanya & 30 & $30 \%$ \\
\hline
\end{tabular}

Dalam kaitannya dengan kamus yang menjadi acuan pengguna, diperlukan suatu terobosan berupa pengembangan kamus pedagogis yang mempunyai fungsi informasi sejarah, sistem ejaan suatu bahasa, pungtuasi, cara pemakaian, pelafalan, morfologi, sintaksis, kata dasar, beserta contoh penggunaannya. ${ }^{23}$ Karena dalam mempelajari bahasa asing, khususnya bahasa Arab tidak lepas dari kebutuhan akan kamus untuk menunjang pembelajaran. Mungkin dengan misalkan mengembangkan kamus saku sebagai salah satu media pembelajaran bahasa Arab yang dapat memudahkan pemahaman dalam suatu buku ajar. Kamus saku mencakup terjemahan kosakata sulit dalam buku ajar sesuai dengan tema yang dibahas. ${ }^{24}$ Kebutuhan kamus untuk mahasiswa sendiri dinilai suatu keniscayaan. Jika seseorang ingin mengetahui makna yang terkandung dalam suatu teks berbahasa Arab, tentu tidak mungkin bagi pembelajar pemula untuk

22 Agung Setiyawan, "Problematika Penggunaan Kamus Arab-Indonesia Dalam Pembelajaran Tarjamah Di Pusat Pengembangan Bahasa UIN Sunan Kalijaga Yogyakarta," Arabia 8, no. 1 (2017): 89, https://journal.iainkudus.ac.id/index.php/Arabia/article/view/1934.

${ }^{23}$ Encep Rustandi, "Kamus Dwibahasa Arab-Indonesia Untuk Pembelajar Pemula," Edusentris 3, no. 2 (2016): 188, https://doi.org/10.17509/edusentris.v3i2.217.

${ }^{24}$ Kaamiliyah Fathanah dkk., "Penggunaan Kamus Musa'id Lil Arabiyah Baina Yadaik Sebagai Media Pembelajaran Bahasa Arab Mahasiswi Semester Satu STAI AS-SUNNAH Medan Tahun Ajaran 2019," Shaut al Arabiyyah 9, no. 1 (2021): 61-68, https://doi.org/10.24252/saa.v9i1.20019. 
mengetahui arti kalimat yang ada. Maka dibutuhkannya kamus untuk menunjang pemahaman seorang penerjemah. Hal ini sesuai dengan hasil survei terkait frekuensi mahasiswa dalam penggunaan kamus untuk menerjemahkan sebagaimana dalam tabel 4 .

Tabel 4. Frekuensi mahasiswa dalam menggunakan kamus

\begin{tabular}{ccc}
\hline Jawaban & Frekuensi & Persentase \\
\hline Selalu & 33 & $33 \%$ \\
Sering & 45 & $45 \%$ \\
Jarang & 19 & $19 \%$ \\
Tidak Pernah & 3 & $3 \%$ \\
\hline
\end{tabular}

Saat ini kemajuan teknologi tidak bisa dibendung, meskipun di Indonesia kamus cetak tetap eksis dan terus berkembang, para leksikolog di Indonesia juga harus mulai mengadakan pengembangan kamus berbentuk digital yang berbasis Mobile. Sehingga mampu memenuhi kebutuhan pengguna khususnya para mahasiswa era milenial, yang saat ini lebih suka mengakses segala sesuatu dengan ponselnya. ${ }^{25}$ Hal tersebut didukung dengan hasil survei dalam tabel 5 terkait jenis kamus yang menjadi favorit mahasiswa dalam menerjemahkan teks berbahasa Arab.

Tabel 5. Jenis kamus yang digunakan untuk menerjemah

\begin{tabular}{ccc}
\hline Jenis Kamus & Frekuensi & Persentase \\
\hline Kamus cetak & 10 & $10 \%$ \\
Kamus digital & 32 & $32 \%$ \\
Kamus cetak \& digital & 58 & $58 \%$ \\
\hline
\end{tabular}

Keberadaan kamus sendiri tak dapat dipisahkan dari suatu proses pendidikan, khususnya dalam mempelajari bahasa asing. Dalam sejarahnya, eksistensi kamus bahasa Arab mengalami berbagai perubahan bentuk. Baik dari segi fisiknya ataupun dalam sistematika penyusunan kamus tersebut. Sedangkan kecenderungan mahasiswa terhadap kamus bahasa Arab lebih menonjolkan pada aspek kepraktisan dan kemudahan karena menggunakan kecanggihan teknologi komunikasi dan informasi terbaru. Selain hal tersebut, rendahnya kemampuan tata bahasa Arab menjadikan salah satu faktor penting belum maksimalnya kemanfaatan kamus yang mampu dipergunakan dengan baik oleh mahasiswa. ${ }^{26}$ Mengenai persepsi mahasiswa terkait penggunaan kamus cetak sudah tidak perlu digunakan lagi karena sudah ada kamus digital di era Society 5.0 ini terinci dalam tabel 6.

${ }^{25}$ R. Taufiqurrochman, "Masterpiece Kamus Bahasa Arab Karya Literasi Ulama Nusantara dari Masa ke Masa," Research (Malang: Universitas Islam Negeri Maulana Malik Ibrahim, 2018), http://repository.uin-malang.ac.id/6132/.

${ }^{26}$ Ahmad Syagif Hannany Mustaufiy dan Anwar Sadat, "Analisis Preferensi Mahasiswa Terhadap Penggunaan Kamus Dalam Mempelajari Bahasa Arab," AL-AF'IDAH: Jurnal Pendidikan Bahasa Arab Dan Pengajarannya 4, no. 1 (2020): 1-17, https://doi.org/10.52266/al-afidah.v4i1.462. 
Tabel 6. Persepsi mahasiswa tentang tidak diperlukannya lagi kamus cetak di era Society 5.0

\begin{tabular}{ccc}
\hline Jawaban & Frekuensi & Persentase \\
\hline Sangat setuju & 6 & $6 \%$ \\
Setuju & 54 & $54 \%$ \\
Tidak setuju & 36 & $36 \%$ \\
Sangat tidak setuju & 4 & $4 \%$ \\
\hline
\end{tabular}

Terkait tingkat kepraktisan antara kamus digital dan kamus cetak, menurut temuan Hastang bahwa kamus bahasa Arab berbasiskan android (digital) lebih efektif untuk dipakai sebagai alat penunjang saat menerjemah. Hal tersebut meliputi: 1) aspek pencarian makna kosakata, 2) aspek penggunaan yang sangat memudahkan, 3) tidak memerlukan waktu lama, dan 4) dapat dibawa ke mana pun. ${ }^{27}$ Secara umum mahasiswa juga beranggapan bahwa penggunaan kamus digital lebih efektif dalam menerjemahkan teks bahasa Arab dibandingkan dengan menggunakan kamus cetak tergambarkan pada tabel 7.

Tabel 7. Persepsi mahasiswa tentang keefektifan kamus digital dibanding kamus cetak

\begin{tabular}{ccc}
\hline Jawaban & Frekuensi & Persentase \\
\hline Sangat setuju & 16 & $16 \%$ \\
Setuju & 64 & $64 \%$ \\
Tidak setuju & 19 & $19 \%$ \\
Sangat tidak setuju & 1 & $1 \%$ \\
\hline
\end{tabular}

Mesin penerjemah tidak semua dapat menerjemahkan kalimat sesuai konteks yang dikehendaki. Sebagaimana hasil temuan Omar Jabak yang menyatakan bahwa google translate tidak dapat selalu diandalkan untuk melakukan terjemahan karena tidak selalu dapat menemukan kata atau ekspresi leksikal yang tepat dan sesuai untuk konteks tertentu. Belum lagi kesalahan sintaksis yang dihasilkan dari terjemahan literal (harfiah) alat tersebut. Kesalahan leksikal dan sintaksis seperti itu pasti akan muncul dalam jenis terjemahan karena dalam suatu bahasa yang diterjemahkan memiliki sistem linguistik dan budaya yang berbeda. Artinya, terjemahan mesin tidak dapat menggantikan terjemahan buatan manusia, terutama ketika terjemahan dilakukan dalam pasangan bahasa yang berbeda. ${ }^{28}$

Menggunakan kamus digital belum tentu apa yang telah diterjemahkan benar. Jadi saat menerjemahkan tidak bisa hanya terfokus pada teks terjemahan dari aplikasi, melainkan juga perlu pemahaman dan penyesuaian konteks yang kehendaki. Menggunakan kamus digital seperti google translate, memang cukup

27 Hastang Hastang, "Efektifitas Kamus Bahasa Arab Berbasis Aplikasi Android Dalam Menerjemahkan Qiraah," Didaktika: Jurnal Kependidikan 11, no. 1 (2019): 112, https://doi.org/10.30863/didaktika.v11i1.158.

28 Omar Jabak, "Assessment of Arabic-English Translation Produced by Google Translate," International Journal of Linguistics, Literature and Translation (IJLLT) 2, no. 4 (2019): 238, https://papers.ssrn.com/sol3/papers.cfm?abstract_id=3441139. 
mudah. Namun, terkadang bahasa yang dihasilkan tidak seutuhnya bisa dipahami dengan baik karena terjemahan robot atau memanfaatkan kecerdasan buatan (artificial Intelligence). Mengenai hal tersebut, persepsi mahasiswa masih terjebak akan kepraktisan dalam penggunaan kamus digital. Artinya masih banyak mahasiswa hanya memakai hasil terjemahan kamus digital secara langsung tanpa melihat kembali pada berbagai aspeknya sebagaimana hasil survei pada tabel 8.

Tabel 8. Persepsi mahasiswa tentang akurasi hasil terjemahan kamus digital

\begin{tabular}{ccc}
\hline Jawaban & Frekuensi & Persentase \\
\hline Sangat setuju & 9 & $9 \%$ \\
Setuju & 51 & $51 \%$ \\
Tidak setuju & 38 & $38 \%$ \\
Sangat tidak setuju & 2 & $2 \%$ \\
\hline
\end{tabular}

Dewasa ini kamus bahasa Arab jika dilihat dari segi jenisnya terbagi menjadi dua macam yaitu kamus cetak dan kamus digital. Secara umum penggunaan kamus bahasa Arab cetak melalui pencarian kata secara alfabetis yaitu berupa huruf awal dari kata dasarnya. Sedangkan dalam kamus bahasa Arab digital terdiri dari kamus online dan kamus yang berupa aplikasi (software). Penggunaan kamus digital secara umum berupa bentuk artikulasi (pengucapan kata) maksudnya berupa huruf awal penyebutan suatu kata. Karenanya, penggunaan kamus digital baik online ataupun berupa aplikasi dianggap lebih memudahkan, bersifat lebih efektif dan efisien tanpa penguasaan ilmu shorof secara mendalam. ${ }^{29}$ Sedangkan hasil temuan Hafidz Azmi, dkk menyatakan bahwa secara umum mahasiswa studi Arab memerlukan kamus dalam proses belajar bahasa asing; sering memakai kamus; lebih sering menggunakan kamus digital dibanding kamus versi cetak; kamus digital lebih efektif dibanding kamus cetak; kamus cetak akan jarang dipakai; kamus digital berperan penting; di antara kamus digital yang menjadi favorit adalah Al Ma'any. ${ }^{30}$ Sedangkan hasil survei menyatakan bahwa kamus yang menjadi favorit mahasiswa adalah Google Translate sebagaimana dalam Tabel 9.

Tabel 9. Jenis kamus favorit mahasiswa

\begin{tabular}{ccc}
\hline Jenis Kamus & Frekuensi & Persentase \\
\hline Google Translate (digital) & 54 & $54 \%$ \\
Kamus Al-Munawwir (cetak) & 19 & $19 \%$ \\
Al-Ma'any (digital) & 16 & $16 \%$ \\
Kamus Arab Mahmud Yunus (cetak) & 7 & $7 \%$ \\
Kamus lainnya & 4 & $4 \%$ \\
\hline
\end{tabular}

${ }^{29}$ Besse Wahida, "Kamus Bahasa Arab Sebagai Sumber Belajar (Kajian Terhadap Penggunaan Kamus Cetak Dan Kamus Digital)," At-Turats 11, no. 1 (2017), https://doi.org/10.24260/atturats.v11i1.870.

${ }^{30}$ Hafidz Azmi, Ismi Wafda Maulidiyah, dan Miftah Fauzi Sutisna, "Peran Kamus Digital Arab Bagi Mahasiswa Studi Arab Di Era 4.0," Multaqa Nasional Bahasa Arab 1, no. 1 (2018): 1-10, https://munasbauai.com/index.php/mnba/article/view/30. 
Kemudian pada akhir akhir penulis menanyakan terkait kesulitan yang secara umum dihadapi Mahasiswa. Dari hasil kuesioner yang disebarkan dapat diambil poin-poin kesulitan mahasiswa dalam menerjemahkan teks bahasa Arab yaitu sebagai berikut: 1) Kesulitan ketika menemukan teks yang panjang. 2) Kesulitan saat menemui kosakata baru ataupun penempatan kata. 3) Tidak memiliki latar belakang pendidikan pondok pesantren atau sekolah agama. 4) Teks Arab memiliki karakteristik yang berbeda, karena jika salah harkat saja sudah beda arti. 5) Sering terbalik-balik dalam penyusunan kalimatnya. 6) Perlunya penguasaan Nahwu dan Shorof yang baik. 7) Sulitnya memahami uslub (gaya bahasa) Arab.

\section{Kesimpulan}

Kemajuan teknologi menjadikan seluruh aspek pendidikan menjadi tak terbendung. Sumber belajar dapat didapatkan hanya dengan mengakses internet. Kemudahan tersebut, terkadang menjadikan mahasiswa menyukai hal yang serba instan tak terkecuali dalam hal menerjemahkan. Berdasarkan paparan dan analisis data di atas, simpulan penelitian menyatakan bahwa mahasiswa secara umum terkait persepsi mahasiswa dapat dipetakan dalam beberapa hal berikut: 1) Tingkat kemampuan mahasiswa dalam menerjemahkan masih rendah. 2) Mahasiswa masih banyak mengalami kesulitan, di samping itu masih belum bisa menggunakan kamus dengan benar. 3) Kamus masih dibutuhkan baik kamus digital maupun kamus cetak. 4) Google translate menjadi kamus favorit mahasiswa. Adapun hasil yang diperoleh melalui riset singkat ini tidak bermaksud untuk menggeneralisir pola atau perilaku kecenderungan mahasiswa secara keseluruhan karena keterbatasan fokus penelitian dan tingkatan mahasiswa yang menjadi objek studi. Penelitian lebih lanjut dapat menitik beratkan kepada subjek lain pada tingkatan yang berbeda. Selain hal itu, diperlukan pelatihan khusus dalam penggunaan kamus di awal mata kuliah pada jenjang pendidikan tinggi bagi mahasiswa.

\section{Daftar Pustaka}

Al-Faraj, Muhammad Ahmad Abu. Al-Ma'ajim Al-Lughawiyah fi Dhau'i Dirasat Ilmi Al-Lughah Al-Hadits. Beirut: Daar An-Nahdlah Al-Arabiyah, 1966.

Al-Qasimy, Ali. Ilm Al-Lughah wa Shina'ah al-Mu'jam. Riyadh: Jami'ah Al-Mulk Su'ud, 1991.

Azmi, Hafidz, Ismi Wafda Maulidiyah, dan Miftah Fauzi Sutisna. "Peran Kamus Digital Arab Bagi Mahasiswa Studi Arab Di Era 4.0.” Multaqa Nasional Bahasa Arab 1, no. 1 (2018): $1-10$. https://munasbauai.com/index.php/mnba/article/view/30.

Bahruddin, Uril. Afaq Al-Ma'ajim Al-Arabiyyah. Malang: CV Lisan Arabi, 2020. http://repository.uin-malang.ac.id/6004/. 
Belkhouche, B., H. Harmain, H. Al Taha, dan L. Al Najjar. "What is a modern Arabic dictionary?," 67-70. Abu Dhabi: Institute of Electrical and Electronics Engineers, 2011. https://doi.org/10.1109/innovations.2011.5893870.

Deguchi, Atsushi, Chiaki Hirai, Hideyuki Matsuoka, Taku Nakano, Kohei Oshima, Mitsuharu Tai, dan Shigeyuki Tani. "What Is Society 5.0?" Dalam Society 5.0: A People-Centric Super-Smart Society, 1-23. Singapore: Springer, 2020. https://doi.org/10.1007/978-981-15-2989-4_1.

Fathanah, Kaamiliyah, Sulton Bigadaran, Nur Hasan, dan Wildana Wargadinata. “Penggunaan Kamus Musa'id Lil Arabiyah Baina Yadaik Sebagai Media Pembelajaran Bahasa Arab Mahasiswi Semester Satu STAI AS-SUNNAH Medan Tahun Ajaran 2019." Shaut al Arabiyyah 9, no. 1 (2021): 61-68. https://doi.org/10.24252/saa.v9i1.20019.

Hanifah, Umi. "Urgensi Pembelajaran Menerjemah Arab-Indonesia Pada Perguruan Tinggi Agama Islam Di Indonesia." Alfazuna: Jurnal Pembelajaran Bahasa Arab dan Kebahasaaraban 2, no. 2 (2018): 204. https://doi.org/10.15642/alfazuna.v2i2.259.

Hastang, Hastang. "Efektifitas Kamus Bahasa Arab Berbasis Aplikasi Android Dalam Menerjemahkan Qiraah." Didaktika: Jurnal Kependidikan 11, no. 1 (2019): 112. https://doi.org/10.30863/didaktika.v11i1.158.

Hayani, Fitra. "Leksikografi Arab (Sebuah Kajian Linguistik Terapan)." Shaut al Arabiyyah 7, no. 1 (2019): 1-12. https://doi.org/10.24252/saa.v1i1.7786.

Hidayatullah, Moch. Syarif. Jembatan Kata: Seluk-Beluk Penerjemahan ArabIndonesia. Jakarta: Grasindo, 2017.

Holcomb, Zealure C. Fundamentals of Descriptive Statistics. London: Routledge, 2016.

Jabak, Omar. "Assessment of Arabic-English Translation Produced by Google Translate." International Journal of Linguistics, Literature and Translation $\begin{array}{lllll}\text { (IJLLT) } & 2, & \text { no. } & 4 & \text { (2019): }\end{array}$ https://papers.ssrn.com/sol3/papers.cfm?abstract_id=3441139.

Khasanah, Habib Bawafi, dan Asyief El Qorny. "Kamus Al-Munawwir Dalam Bingkai Leksikologi-Semantik." Jurnal Al Fikrah 3, no. 2 (2021): 125. http://jurnal.stit-almuslihuun.ac.id/index.php/jurnal/article/view/99.

Khoirurrijal, Khotijah, Ahmad Arifin, Ani Susilawati, dan Nawang Wulandari. Interpretasi Makna (Prosedur Penerjemahan Arab - Indonesia). Yogyakarta: Idea Press, 2019.

Mustaufiy, Ahmad Syagif Hannany, dan Anwar Sadat. "Analisis Preferensi Mahasiswa Terhadap Penggunaan Kamus Dalam Mempelajari Bahasa Arab." AL-AF'IDAH: Jurnal Pendidikan Bahasa Arab Dan Pengajarannya 4, no. 1 (2020): 1-17. https://doi.org/10.52266/al-afidah.v4i1.462. 
Ni'mah, Umi Nurun. "Perkembangan 'Ilm Al-Ṣarf Dalam Leksikologi Arab." Adabiyyāt: Jurnal Bahasa Dan Sastra 3, no. 1 (2019): 26-52. https://doi.org/10.14421/ajbs.2019.03102.

Rustandi, Encep. "Kamus Dwibahasa Arab-Indonesia Untuk Pembelajar Pemula." $\begin{array}{llllll}\text { Edusentris } & 3, & \text { no. } & 2 & \text { (2016): }\end{array}$ https://doi.org/10.17509/edusentris.v3i2.217.

Setiyawan, Agung. "Problematika Penggunaan Kamus Arab-Indonesia Dalam Pembelajaran Tarjamah Di Pusat Pengembangan Bahasa UIN Sunan Kalijaga Yogyakarta." Arabia 8, no. 1 (2017): 89. https://journal.iainkudus.ac.id/index.php/Arabia/article/view/1934.

Shalihah, Siti. "Menerjemahkan Bahasa Arab: Antara Ilmu Dan Seni." At-Ta'dib 12, no. 1 (2017): 157. https://doi.org/10.21111/at-tadib.v12i1.867.

Sunaryo, Adi, Ahmad Patoni, dan Umi Basiroh. Pedoman Penyusunan Kamus Dwibahasa. Jakarta: Departemen Pendidikan dan Kebudayaan, 1990. http://repositori.kemdikbud.go.id/3297/.

Suryaningrum, Kristien Margi. "Siapkah Indonesia Menyosong Society 5.0 dengan Seiring Perkembangan Big Data yang Semakin Pesat?" School of Computer Science - Binus University. Diakses 19 Desember 2021. https://socs.binus.ac.id/2020/11/01/siapkah-indonesia-menyosongsociety-5-0-dengan-seiring-perkembangan-big-data-yang-semakin-pesat/.

Taufiqurrochman, R. "Advantages and Disadvantages of Arabic Dictionary Applying Morphological System For Learning Arabic in Indonesia." LiNGUA: Jurnal Ilmu Bahasa Dan Sastra 14, no. 2 (2019): 271. https://doi.org/10.18860/ling.v14i2.8316.

———. "Masterpiece Kamus Bahasa Arab Karya Literasi Ulama Nusantara dari Masa ke Masa." Research. Malang: Universitas Islam Negeri Maulana Malik Ibrahim, 2018. http://repository.uin-malang.ac.id/6132/.

Taufiqurrochman, R., dan Dewi Suci. "Student's Perception of E-Dictionary Arabic Indonesian in IR 4.0 Era." Dalam Proceedings of the 2nd International Conference on Quran and Hadith Studies Information Technology and Media in Conjunction with the 1st International Conference on Islam, Science and Technology. Bandung: European Alliance for Innovation, 2018. https://eudl.eu/doi/10.4108/eai.2-10-2018.2295473.

Vaus, David de. Research Methods for Postgraduates. Disunting oleh Tony Greenfield dan Sue Greener. Third edition. Chichester, UK ; Hoboken, NJ: John Wiley \& Sons, 2016.

Wahab, Muhbib Abdul. "Peta Perkembangan Leksikografi Arab Di Indonesia: Studi Kritis Atas Kamus Karya Mahmud Yunus." Arabi : Journal of Arabic Studies 2, no. 1 (2017): 19-36. https://doi.org/10.24865/ajas.v2i1.31. 
Wahida, Besse. "Kamus Bahasa Arab Sebagai Sumber Belajar (Kajian Terhadap Penggunaan Kamus Cetak Dan Kamus Digital)." At-Turats 11, no. 1 (2017). https://doi.org/10.24260/at-turats.v11i1.870.

Widayat, Prabowo Adi. "Kitābu Al-'Ain: Metode Penggunaan Dan Pengaruhnya Dalam Perkembangan Kosakata Bahasa Arab." Al-Fathin: Jurnal Bahasa Dan Sastra Arab 2, no. 01 (2019): 95. https://doi.org/10.32332/alfathin.v2i2.1424.

Zahrah, Humairatuz, Wildana Wargadinata, dan Nurhasan Abdul Barry. "Analisis EDictionarry 'Arab-Indonesia' yang Tersedia di Playstore dengan Pendekatan Leksikologi." Shaut al Arabiyyah 9, no. 1 (2021): 1-10. https://doi.org/10.24252/saa.v9i1.21494. 
